\title{
PENGARUH PAPARAN KRONIS TIMBAL (Pb) TERHADAP TEKANAN DARAH PETUGAS PARKIR DI PASAR BESAR KOTA MALANG
}

\author{
EFFECT OF LEAD (PB) CHRONIC EXPOSURE TO BLOOD PRESSURE OF PARKING \\ ATTENDANT \\ IN PASAR BESAR MALANG
}

Dwi Soelistyoningsih, Yohanes Edison Mau

E-mail Correspondence : soelistyoningsih@gmail.com

\begin{abstract}
Currently, the use of motor vehicles is increasing. The result of fuel combustion vehicles are likely to cause air pollution. One of them is lead (Pb) which can endanger the health and damage the environment. The purpose of this study was to determine the effect of lead $(\mathrm{Pb})$ chronic exposure on blood pressure of parking attendant at Pasar Besar Malang. This research is observational analytic with cross sectional study design. There were 23 parking attendants at Pasar Besar Malang as subjects. After signing an informed consent, subjects were examined in the blood Pb levels, systolic blood pressure, diastolic blood pressure, and MAP (Mean Arterial Pressure). The results of this study found that the levels of lead in the blood are high 11.33 times more at risk to have a systolic blood pressure than normal, even though the value is not significant $(p>0.05)$. Pb levels in the blood are more at risk 12.00 times higher has exceeded normal diastolic blood pressure was significantly $(p<0.05)$. Pb levels in the blood are more at risk of 11.33 times higher value than normal MAP was significantly $(p<0.05)$. The conclusion from this study that the high Pb levels in the blood increase the risk to have higher systolic blood pressure, diastolic blood pressure, and MAP than normal.
\end{abstract}

Keywords: Lead (Pb), systolic blood pressure, diastolic blood pressure, mean arterial pessure (MAP) 


\section{ABSTRAK}

Saat ini, penggunaaan kendaraan bermotor semakin meningkat. Hasil pembakaran bahan bakar kendaraan tersebut banyak menyebabkan polusi udara. Salah satunya berupa timbal $(\mathrm{Pb})$ yang dapat membahayakan kesehatan dan merusak lingkungan. Tujuan dari penelitian ini adalah untuk mengetahui pengaruh paparan kronis Timbal $(\mathrm{Pb})$ terhadap tekanan darah petugas parkir Pasar Besar kota Malang. Penelitian ini berupa observasional analitik dengan desain penelitian cross sectional. Subyek penelitian adalah tukang parkir di Pasar Besar kota Malang sebanyak 23 orang, setelah menandatangani informed consent subyek dilakukan pemeriksaan kadar $\mathrm{Pb}$ dalam darah, tekanan darah sistolik, tekanan darah diastolik, dan MAP (Mean Arterial Pressure). Hasil penelitian ini didapatkan bahwa kadar $\mathrm{Pb}$ dalam darah yang tinggi lebih beresiko 11,33 kali memiliki tekanan darah sistolik melebihi normal, walaupun nilainya tidak signifikan $(\mathrm{p}>0,05)$. Kadar $\mathrm{Pb}$ dalam darah yang tinggi lebih beresiko 12,00 kali memiliki tekanan darah diastolik melebihi normal secara signifikan $(\mathrm{p}<0,05)$. Kadar $\mathrm{Pb}$ dalam darah yang tinggi lebih beresiko 11,33 kali memiliki nilai MAP melebihi normal secara signifikan $(\mathrm{p}<0,05)$. Kesimpulan dari penelitian ini bahwa kadar $\mathrm{Pb}$ yang tinggi dalam darah meningkatkan resiko untuk memiliki tekanan darah sistolik, tekanan darah diastolik, serta nilai MAP yang melebihi normal.

\section{Kata kunci : Timbal (Pb), tekanan darah sistolik, tekanan darah diastolik, mean arterial pessure (MAP)}

\section{PENDAHULUAN}

Penyakit akibat kerja sebagian besar disebabkan oleh pajanan/paparan zat kimia beracun sebagai hasil pengolahan bahan mentah, produk proses industri, maupun limbah industri (Harrianto, 2008). Salah satu dampak negatif yang didapatkan adalah tingginya tingkat polusi udara lingkungan kota, sebagai hasil emisi gas pembuangan kendaraan bermotor. Dilihat dari sumbernya, pencemaran udara terbesar berasal dari asap buangan kendaraan bermotor. Adapun unsur yang terdapat dari hasil emisi gas buang yang berbahaya diantaranya adalah unsur timbal atau Plumbum $(\mathrm{Pb})$.

Timbal $(\mathrm{Pb})$ sebenarnya sudah ada di dalam bahan bakar bensin. Oleh karena mesin kendaraan tidak sempurna dalam proses pembuangannya, maka timbal $(\mathrm{Pb})$ menjadi unsur yang terlepas bebas di udara (Rosyidah, 2010). Tidak musnahnya timbal $(\mathrm{Pb})$ dalam dalam peristiwa pembakaran pada mesin menyebabkan jumlah timbal $(\mathrm{Pb})$ yang dibuang ke udara melalui asap buangan kendaraan bermotor menjadi sangat tinggi (Girsang, 2008). Pajanan timbal $(\mathrm{Pb})$ pada manusia dapat menimbulkan berbagai efek negatif pada kesehatan, yaitu pada saraf pusat dan saraf tepi (menurunkan daya konsentrasi, gangguan tidur dan kecemasan), sistem kardiovaskuler (menyebabkan hipertensi), sistem hematopoetik (anemia), ginjal, pencernaan, sistem reproduksi, dan bersifat karsinogenik (Paul dan Jhonly, 2009; Rosyidah, 2010).

Sampai saat ini, hipertensi masih merupakan tantangan besar di Indonesia. Sesuai data Riskesdas 2013, prevalensi hipertensi di Indonesia adalah sebesar 25,8\%. Hasil penelitian Zamhir (2004) menunjukkan prevalensi hipertensi di Pulau Jawa $41,9 \%$, dengan kisaran di masingmasing provinsi $36,6 \%-47,7 \%$. Terdapat bukti bahwa polutan timbal $(\mathrm{Pb})$, diindikasikan sebagai faktor pemicu tekanan darah tinggi, meskipun diperlukan lebih banyak penelitian mengenai hubungan ini (Paul dan Jhonly, 2009).

Berbagai macam mekanisme diduga berkontribusi terhadap peningkatan tekanan darah diakibatkan paparan kronis timbal $(\mathrm{Pb})$. Timbal berpengaruh terhadap sistem hormonal dan neural yang berperan dalam regulasi resistensi pembuluh darah perifer, denyut jantung, serta cardiac ouput (Vaziri and Sica 2004 dalam U.S. DEPARTMENT OF HEALTH AND HUMAN SERVICES, 2007). Timbal $(\mathrm{Pb})$ menginduksi terjadinya hipertensi pada mencit dengan menurunkan kadar Nitrogen Oksida (NO) yang berperan 
penting dalam regulasi tekanan darah baik melalui pengaturan perifer maupun sentral. Penurunan NO dikaitkan dengan stress oksidatif dan peningkatan aktivitas ROS (Reactive Oxygen Species) (Ding et al. 2001 dalam U.S. DEPARTMENT OF HEALTH AND HUMAN SERVICES, 2007).

Menurut Kepres No.22 tahun 1993 ditentukan 31 jenis penyakit akibat kerja, salah satunya adalah penyakit yang disebabkab oleh timbal atau persenyawaannya yang beracun (Harrianto, 2009). Pekerja yang terpapar timbal secara terus menerus akan berisiko keracunan dan dapat terganggu kesehatannya, selanjutnya menurunkan produktivitas kerja. Petugas parkir merupakan kelompok pekerja yang berisiko tinggi terpapar dengan timbal, melalui emisi gas kendaraan bermotor. Paparan timbal secara terus menerus akan berisiko menimbulkan keracunan dan dapat terganggu kesehatannya, selanjutnya menurunkan produktivitas kerja. Oleh karena itu, peneliti ingin mengetahui pengaruh paparan timbal $(\mathrm{Pb})$ terhadap tekanan darah petugas parkir Pasar Besar kota Malang.

\section{METODE PENELITIAN}

\section{Subyek dan Desain Penelitian}

Subyek penelitian ini adalah petugas parkir yang ada di Pasar Besar Kota Malang, laki-laki, tanpa riwayat hipertensi, ataupun mengkonsumsi obat anti hipertensi, dan telah menandatangani informed consent. Jenis penelitian adalah penelitian observasional analitik dengan desain penelitian cross sectional. Sampel dilakukan pengukuran kadar timbal $(\mathrm{Pb})$ dalam darah, tekanan darah sistolik, tekanan darah diastolik, dan MAP (Mean Arterial Pressure).

\section{Pengukuran Kadar Timbal(Pb) dalam darah dan tekanan darah}

Pengukuran kadar timbal $(\mathrm{Pb})$ dalam darah dilakukan di laboratorium dengan menggunakan alat Atomic Absorbtion Spektrophotometer (AAS). Tekanan darah diukur dengan menggunakan sphygmomanometer raksa.
Analisis univariat digunakan untuk menghitung distribusi frekuensi gambaran karakteristik responden. Analisis bivariat dilakukan untuk melihat hubungan antara variabel dependen dengan variabel independen, yakni uji korelasi chi-square. Signifikansi statistik ditentukan jika nilai $p<0.05$. Data akan dianalisa dengan program SPSS versi 19.HASIL PENELITIAN

\section{Karakteristik Responden}

Subyek yang memenuhi kriteria inklusi dan eksklusi sebanyak 23 orang. Karakteristik subyek dapat dilihat pada Tabel 1.

Tabel 1. Karakteristik Responden

\begin{tabular}{lccc}
\hline Karakteristik & Kriteria & $\begin{array}{c}\text { Persentase } \\
(\mathbf{N}=\mathbf{2 3})\end{array}$ \\
\hline Umur & $<23$ tahun & $43,5 \%$ & $(10)$ \\
& $\geq 23$ tahun & $56,5 \%$ & $(13)$ \\
\hline Masa kerja & $<2$ tahun & $13 \%$ & $(3)$ \\
& $\geq 2$ tahun & $87 \%$ & $(20)$ \\
\hline Kelengkapan & Dengan & $17,4 \%$ & $(4)$ \\
APD & APD & $82,6 \%$ & $(19)$ \\
\hline \multirow{3}{*}{ Merokok } & Tanpa APD & & \\
& Tidak & $26,1 \%$ & $(6)$ \\
& merokok & $73,9 \%$ & $(17)$ \\
\hline
\end{tabular}

Tabel 1 menunjukan bahwa petugas parkir yang berumur $<23$ tahun berjumlah 10 orang $(43,5 \%)$ dan petugas parkir yang berumur $\geq 23$ tahun berjumlah 13 orang $(56,5 \%)$. Untuk masa kerja, responden dengan lama kerja $<2$ tahun sebanyak 3 orang $(13,0 \%)$ sedangkan yang bekerja $\geq 2$ tahun sebanyak 20 orang $(87,0 \%)$. Petugas yang menggunakan APD sebanyak 4 orang $(17,4 \%)$ sedangkan responden yang tidak menggunakan APD sebanyak 19 orang $(82 \%)$. Petugas parkir yang memiliki kebiasaan merokok adalah 17 orang $(73,9 \%)$ dan petugas parkir yang tidak memiliki kebiasaan merokok adalah 6 orang $(26,1 \%)$.

\section{Kadar Timbal (Pb) dalam Darah Petugas Parkir}

Berdasarkan pengukuran timbal $(\mathrm{Pb})$ dalam darah responden didapatkan hasil sebagai berikut :

\section{Analisis Data}


Tabel 2 . Distribusi Frekuensi Timbal $(\mathrm{Pb})$ dalam Darah

\begin{tabular}{ccc}
\hline $\begin{array}{c}\text { Timbal (Pb) } \\
\text { dalam } \\
\text { Darah/100mL }\end{array}$ & n & \% \\
\hline $\begin{array}{c}\text { Rendah } \\
<5 \mu \mathrm{g} / 100 \mathrm{~mL}\end{array}$ & 5 & 21,7 \\
\hline $\begin{array}{c}\text { Tinggi } \\
\geq 5 \mu \mathrm{g} / 100 \mathrm{~mL}\end{array}$ & 18 & 78,3 \\
\hline Total & 23 & 100,0 \\
\hline
\end{tabular}

Tabel 2 menunjukkan bahwa kadar timbal $(\mathrm{Pb})$ dalam darah petugas parkir kelompok rendah $(<5 \mu \mathrm{g} / 100 \mathrm{~mL})$ sebanyak 5 orang $(21,7 \%)$ dan petugas parkir yang memiliki kadar timbal $(\mathrm{Pb})$ tinggi $(\geq 5 \mu \mathrm{g} / 100 \mathrm{~mL})$ sebanyak 18 responden $(78,3 \%)$.

\section{Tekanan Darah Petugas Parkir}

Berdasarkan hasil pengukuran tekanan darah responden didapatkan hasil sebagai berikut :

Tabel 3 . Hasil pengukuran tekanan darah petugas parkir

\begin{tabular}{lll}
\hline $\begin{array}{l}\text { Tekanan } \\
\text { Darah }\end{array}$ & $\begin{array}{l}\text { Nilai } \\
\text { tekanan } \\
\text { darah } \\
(\mathbf{m m H g})\end{array}$ & $\begin{array}{l}\text { Persentase } \\
\mathbf{( N = 2 3 )}\end{array}$ \\
\hline Sistolik & $<120$ & $15 \%(3)$ \\
\hline
\end{tabular}

\begin{tabular}{lll}
\hline & $\geq 120$ & $85 \%(20)$ \\
\hline Diastolik & $<90$ & $21,7 \%(5)$ \\
& $\geq 90$ & $78,3 \%(18)$ \\
\hline Mean & $70-99$ & $21,7 \%(5)$ \\
Arterial & $\geq 100$ & $78,7 \%(18)$ \\
Pressure & & \\
(MAP) & & \\
\hline
\end{tabular}

Tabel 3 menunjukkan bahwa petugas parkir yang memiliki tekanan darah sistolik $<120$ mmHg sebanyak 3 orang (15\%) sedangkan petugas parkir yang tekanan darah sistoliknya $\geq 120 \mathrm{mmHg}$ sebanyak 20 orang (85\%). Petugas parkir yang memiliki tekanan darah diastolik $<90 \quad \mathrm{mmHg}$ sebanyak 5 orang $(21,7 \%)$ sedangkan petugas parkir yang tekanan darah diastoliknya $\geq 90 \mathrm{mmHg}$ sebanyak 18 orang (78,3\%). Petugas parkir yang memiliki MAP 70-99 mmHg sebanyak 5 orang $(21,7 \%)$ sedangkan petugas parkir dengan MAP $\geq 100 \mathrm{mmHg}$ sebanyak 18 orang $(78,3 \%)$.

\section{Pengaruh paparan kronis Timbal $(\mathrm{Pb})$ terhadap Tekanan Darah Petugas Parkir} Pengaruh paparan kronis timbal $(\mathrm{Pb})$ terhadap tekanan darah Petugas Parkir di Pasar Besar dapat dilihat pada tabel-tabel berikut :

Tabel 4 Kadar $\mathrm{Pb}$ terhadap tekanan darah sistolik petugas parkir

\begin{tabular}{|c|c|c|c|c|c|}
\hline \multirow[t]{2}{*}{$\begin{array}{l}\text { Kadar Pb } \\
(\mu \mathrm{g} / 100 \mathrm{~mL})\end{array}$} & $\begin{array}{l}\text { Tekana } \\
(\mathrm{mmHg}\end{array}$ & h sistolik & \multirow[t]{2}{*}{ Total } & \multirow[t]{2}{*}{$\begin{array}{l}\text { Odds Ratio } \\
(95 \% \text { CI })\end{array}$} & \multirow[t]{2}{*}{$P$ value } \\
\hline & $<120$ & $\geq 120$ & & & \\
\hline$<5$ & 2 & 3 & 5 & \multirow{3}{*}{11.33} & \multirow{3}{*}{0.078} \\
\hline$\geq 5$ & 1 & 17 & 18 & & \\
\hline Total & 3 & 20 & 23 & & \\
\hline
\end{tabular}

Tabel 5. Kadar $\mathrm{Pb}$ terhadap tekanan darah diastolik petugas parkir

\begin{tabular}{|c|c|c|c|c|c|}
\hline \multirow[t]{2}{*}{$\begin{array}{l}\text { Paparan Pb } \\
(\mu \mathrm{g} / 100 \mathrm{~mL})\end{array}$} & $\begin{array}{l}\text { Tekana } \\
(\mathrm{mmHg}\end{array}$ & h diastolik & \multirow[t]{2}{*}{ Total } & \multirow[t]{3}{*}{$(95 \% \mathrm{CI})$} & $P$ value \\
\hline & $<89$ & $\geq 90$ & & & \multirow{4}{*}{$0.035^{*}$} \\
\hline$<5$ & 3 & 2 & 5 & & \\
\hline$\geq 5$ & 2 & 16 & 18 & \multirow[t]{2}{*}{12.00} & \\
\hline Total & 5 & 18 & 23 & & \\
\hline
\end{tabular}

Tabel 6 Kadar Pb terhadap Mean Arterial Pressure (MAP) petugas parkir

\begin{tabular}{llllll}
\hline $\begin{array}{l}\text { Kadar } \mathrm{Pb} \\
(\mu \mathrm{g} / 100 \mathrm{~mL})\end{array}$ & $\begin{array}{l}\text { Mean Arterial Pressure } \\
(\mathrm{MAP})(\mathrm{mmHg})\end{array}$ & Total & $\begin{array}{l}\text { Odds Ratio } \\
(95 \% \mathrm{CI})\end{array}$ & P value \\
\cline { 2 - 4 } & $70-99$ & $\geq 100$ & & \multirow{2}{*}{12.00} & $0.035^{*}$ \\
\hline$<5$ & 3 & 2 & 5 & & \\
\hline$\geq 5$ & 2 & 16 & 18 & & \\
\hline Total & 5 & 18 & 23 & &
\end{tabular}




\section{PEMBAHASAN}

Dalam penelitian ini, masa kerja dibagi menjadi 2 kategori yaitu lama kerja $<2$ tahun dan lama kerja $\geq 2$ tahun. Petugas parkir dengan lama kerja $<2$ tahun terdapat 3 responden $(13,0 \%)$ dan lama kerja $\geq 2$ tahun sebanyak 20 responden $(87,0 \%)$. Lama seorang tenaga kerja di perusahaan atau pabrik identik dengan paparan lingkungan yang didapatkan selama tenaga kerja tersebut bekerja, dengan kata lain dapat dikatakan bahwa semakin lama seorang tenaga kerja bekerja di lingkungan kerja tertentu, maka paparan polutan yang diterima pekerja itu semakin besar (Harianto, 2009).

Dalam penelitian ini penggunaan APD dibagi dalam 2 kategori yaitu menggunakan sarung tangan dan masker (lengkap) dan tidak menggunakan sarung tangan dan masker (tidak lengkap). Petugas parkir dengan penggunaan APD tidak lengkap memiliki jumlah yang lebih banyak yaitu 19 responden $(82,6 \%)$ dan yang menggunakan APD (lengkap) 4 responden $(17,4 \%)$. Penggunaan APD yang tidak lengkap dapat merugikan pekerja. Penggunaan APD sangatlah penting untuk melindungi tubuh dari bahaya polutan yang ada di lingkungan kerja yang dapat mengganggu kesehatan.

Dalam penelitian ini kadar timbal dalam darah dibagi menjadi 2 kriteria, dimana kadar $\mathrm{Pb}$ dalam darah $<5$ $\mu \mathrm{g} / 100 \mathrm{~mL}$ sebanyak 5 responden $(21,7 \%)$ dan kadar $\mathrm{Pb}$ dalam darah $\geq 5 \mu \mathrm{g} / 100 \mathrm{~mL}$ sebanyak 18 responden $(78,3 \%)$. Hal ini menunjukkan bahwa lebih banyak petugas parkir yang di dalam darahnya mengandung timbal $(\mathrm{Pb})$ dalam kadar yang tinggi $(\geq 5$ $\mu \mathrm{g} / 100 \mathrm{~mL})$.

Hasil pengukuran tekanan darah pada petugas parkir didapatkan lebih banyak yang memiliki tekanan sistolik lebih dari normal $(\geq 120 \mathrm{mmHg})$ sebanyak 20 orang dibandingkan dengan yang memiliki tekanan sistolik normal yakni sebanyak 3 orang. Hal ini menunjukkan bahwa lebih banyak petugas parkir yang kemungkinan menderita pre hipertensi, hipertensi stage I, II, atau III dibandingkan mereka yang normal. Dari perhitungan tabel ODDs ratio didapatkan nilai estimasi sebesar 11,33 $(\mathrm{p}=0,078)$, artinya mereka dengan kadar $\mathrm{Pb}$ dalam darah yang tinggi lebih beresiko 11,33 kali memiliki tekanan darah sistolik melebihi normal,walaupun nilainya tidak signifikan $(\mathrm{p}>0,05)$.

Hasil pengukuran tekanan darah pada petugas parkir didapatkan lebih banyak yang memiliki tekanan diastolik lebih dari normal ( $\geq 90 \mathrm{mmHg}$ ) sebanyak 18 orang dibandingkan dengan yang memiliki tekanan diastolik normal yakni sebanyak 5 orang. Hal ini menunjukkan bahwa lebih banyak petugas parkir yang kemungkinan menderita pre hipertensi, hipertensi stage I, II, atau III dibandingkan mereka yang normal. Dari perhitungan tabel ODDs ratio didapatkan nilai estimasi sebesar 12,00 $(\mathrm{p}=0,035)$, artinya mereka dengan kadar $\mathrm{Pb}$ dalam darah yang tinggi lebih beresiko 12,00 kali memiliki tekanan darah diastolik melebihi normal secara signifikan $(\mathrm{p}<0,05)$.

Hasil Mean Arterial Pressure (MAP) pada petugas parkir didapatkan lebih banyak yang memiliki tekanan diastolik lebih dari normal $(\geq 100 \mathrm{mmHg})$ sebanyak 18 orang dibandingkan dengan yang memiliki tekanan diastolik normal (70-99 mmHg) yakni sebanyak 5 orang. Hal ini menunjukkan bahwa lebih banyak petugas parkir yang kemungkinan menderita pre hipertensi, hipertensi stage I, II, atau III dibandingkan mereka yang normal. Dari perhitungan tabel ODDs ratio didapatkan nilai estimasi sebesar 12.00 $(\mathrm{p}=0.035)$, artinya mereka dengan kadar $\mathrm{Pb}$ dalam darah yang tinggi lebih beresiko 12,00 kali memiliki nilai MAP melebihi normal secara signifikan $(p<0,05)$. Nilai MAP lebih dapat menunjukkan perfusi organ atau jaringan dibandingkan tekanan darah sistolik dan memiliki nilai lebih dekat dengan nilai tekanan darah diastolik (Mohrman and Heller, 2006). Menurut Sesso et al.(2000) nilai MAP dapat digunakan sebagai prediktor terhadap resiko penyakit kardiovaskuler.

Kadar timbal $(\mathrm{Pb})$ dalam darah dapat menjadi salah satu penyebab terjadinya hipertensi. Ini dikarenakan, timbal dapat menyebabkan meningkatnya produksi reactive oxygen species atau ROS 
(Vaziri \& Khan, 2007). ROS dapat meningkatkan tekanan darah secara langsung dan mempengaruhi perubahan atherosclerotic dalam darah yang menyebabkan meningkatnya tekanan pembuluh darah arteri dan gangguan jantung (Farmand et al, 2005). Paparan timbal kronis juga menyebabkan meningkatnya oxidative stress, menyebabkan inflammasi dan mengganggu kerja nitric oxide (NO), yang akhirnya memicu proses-proses yang menyebabkan meningkatnya tekanan darah dan penyakit kardiovaskuler (Vaziri \& Khan, 2007). Timbal juga menganggu proses vasodilatasi akibat adanya pengaruh timbal terhadap mekanisme cell-signaling pada lapisan endotel pembuluh darah. Paparan timbal pada mencit berhubungan dengan terjadinya down regulation ekspresi guanylat cyclase, yakni enzim yang berperan dalamproduksi cyclic GMP, yang merupakan mediator proses vasodilatasi akibat NO (Marques et al. 2001 dalam U.S. DEPARTMENT OF HEALTH AND HUMAN SERVICES, 2007). Peningkatan tekanan darah akibat induksi timbal $(\mathrm{Pb})$ juga dikaitkan dengan abnormalitas sistem adrenergik, termasuk peningkatan aktivitas sistem saraf simpatik sentral, peningkatan norepinephrin plasma, dan penurunan jumlah reseptor $\beta$-adrenergik pembuluh darah (Carmignani et al. 2000 dalam U.S. DEPARTMENT OF HEALTH AND HUMAN SERVICES, 2007). Paparan kronik timbal juga mengaktivasi sistem reninangiotensin-aldosteron,baik secara langsung maupun tidak langsung, melalui stimulasi sistemsaraf simpatis. Paparan timbal menyebabkan peningkatan aktivitas renin plasma, angiotensin-convertingenzym (ACE), dan konsentrasi aldosteron plasma. Timbal mempengaruhi konstriksi otot polos pembuluh darah, yang akan mempengaruhi inhibisi aktivitas Na-KATPase dan peningkatan kadar $\mathrm{Ca}^{2+}$ interseluler yang dimungkinkan melalui peningkatan aktivitas protein-kinase $\mathrm{C}$ (Hwang et al. 2001 dalam U.S. DEPARTMENT OF HEALTH AND HUMAN SERVICES, 2007).
Berdasarkan hasil penelitian Rosydah (2010) yang dilakukan pada 25 responden didapatkan responden yang menderita hipertensi sebesar sebesar 13 responden $(57 \%)$, sedangkan yang tidak menderita hipertensi sebesar 12 responden $(48 \%)$. Adapun faktor risiko yang diteliti dalam penelitian ini adalah kadar $\mathrm{Pb}$ dalam darah. Hasil uji statistik hubungan kadar $\mathrm{Pb}$ dalam darah dengan kejadian hipertensi, didapatkan bahwa 14 responden (56\%) yang memiliki kadar $\mathrm{Pb}$ dalam darah tinggi, terdapat 10 responden $(40 \%)$ yang menderita hipertensi dengan $\mathrm{p}=1,201$ ( $\mathrm{P}>$ 0,05). Rata-rata $\mathrm{Pb}$ darah petugas operator SPBU sekitar 24,97 $\mu \mathrm{g} / \mathrm{dl}$ meskipun kadarnya lebih rendah bila dibandingkan dengan batas kadar aman $\mathrm{Pb}$ dalam darah oleh WHO (1977) sekitar 10-25 $\mu \mathrm{g} / \mathrm{dl}$.

\section{KESIMPULAN}

Dari penelitian yang dilakukan diperoleh kesimpulan bahwa kadar timbal $\mathrm{Pb})$ dalam darah yang tinggi akan meningkatkan resiko pada petugas parkir untuk mengalami peningkatan tekanan darah sistolik, tekanan darah diastolik, dan Mean Arterial Pressure (MAP) .

\section{DAFTAR PUSTAKA}

A.T Paul, Jhonly. 2009. Analisis Kadar timbal darah dan Penyakit Hipertensi pada petugas stasiun pengisian bahan bakar di kota Manado. Tesis.

Darmono. 2010. Lingkungan Hidup dan Pencemaran. Universitas Indonesia Press. Jakarta.

Department of Health and Human Service ( JNC 7) Express, 2003. Batasan Hipertensi.

Deyot, Krisostomus Yohanes. 2013. Masa Kerja, Kadar Timbal Darah Dan Kejadian Hipertensi Pada Petugas Parkir Di Jl. Malioboro Yogyakarta. Tesis. Universitas Gajah Mada. Yogyakarta

Girsang, Ermi. 2008. Hubungan kadar timbal di udara ambien dengan timbal dalam darah pada pegawai dinas perhubungan terminal antar kota. Skripsi. Medan 
Pengaruh Paparan Kronis Timbal (Pb) Terhadap Tekanan Darah Petugas Parkir.. | DWI SOELISTYONINGSIH

Gunawan, Lany. 2001 Hipertensi (Tekanan Darah Tinggi). Kanisius : Yogyakarta.

Harrianto, Ridwan.2009. Buku Ajar Kesehatan Kerja. EGC. Jakarta

Kaplan, NM. 2004. Clinical Hipertension, eighth edition. Dallas Texas: Lippincott Williams dan Wilkins.

Mardani, Rina, Tunggul, Dkk. 2005. Kadar Timbal $(\mathrm{Pb})$ dalam darah dan hubungannya dengan Kadar $\mathrm{Hb}$ darah akibat emisi kendaraan bermotor pada petugas DLLAJ di kota Surakarta. Jurnal Bio Smart Vol. 7. No. 1. Hal .60-65 .

URL :(http://google.Com, sitasi tanggal 21 Juli 2015).

Mohrman DE and Heller LJ. 2006. Cardiovascular Physiology.6th ed. New York. McGraw-Hill

Rosyidah Hesti. 2010. Hubungan antara kadar $\mathrm{Pb}$ dalam darah dengan kejadian hipertensi pada operator SPBU.Tesis. Universitas Ahmad Dahlan. Jogja.

URL : (http://journal.ed.asu/epa/, sitasi tanggal 1 juli 2015).

Salvi P. 2012. Pulse Waves, DOI:10.1007/978-88-470-2439-

7 2, Springer-Verlag.Itali.

Sesso HD et al. 2000. Systolic and Diastolic Blood Pressure, Pulse Pressure and Mean Arterial Pressure as Predictor of Cardiovascular Disease Risk in Men. Hypertension. American Heart Association.

Suciani, Sri. 2007. Kadar Timbal dalam Darah Polisi Lalu Lintas dan hubungannya dengan Kadar Hemoglobin.Tesis. Universitas Diponegoro Semarang.

URL : (http://wwwpdpersi.co.id, sitasi tanggal 1 juli 2015).

U.S. DEPARTMENT OF HEALTH AND HUMAN SERVICES, 2007. Toxicology profile for lead. Agency for Toxic Substances and Disease Registry .Georgia

Zamhir, S. 2004. Prevalensi dan determinan hipertensi di indonesia. Jakarta: Jurnal kesehatan
Masyarakat Nasional Volume 1 dan 2.

$U R L$

:(http://www.ehjournal.net/content/ 10/1/28, Sitasi tanggal 20 Juli 2015). 
JURNAL ILMIAH KESEHATAN MEDIAHUSADA ｜ VOLUME 06/NOMOR 02/OKTOBER 2017 